\title{
Becquerel per Microgram
}

National Cancer Institute

\section{Source}

National Cancer Institute. Becquerel per Microgram. NCI Thesaurus. Code C70523.

A unit of specific radioactivity (massic activity) equal to activity of one becquerel of the sample with total mass of one microgram. 